\title{
EVALUATION AND ANALYSIS OF URBAN PASSENGERS TRANSPORT MODES OPERATION PERFORMANCE \& EFFICIENCY
}

\author{
Owais $M, M^{1}$, Salah $G$, Oneib $M^{2}$, and Abbas, $Y^{3}$ \\ ${ }^{1}$ Demonstrator, ${ }^{2}$ Assistant Professor, ${ }^{3}$ Professor \\ Civil Engineering Department, Assiut University, Assiut, Egypt
}

(Received February 19, 2011 Accepted April 2, 2011)

While the demand for transportation is growing rapidly, many problems are facing planners and traffic operators in urban areas; such as; low performance and efficiency levels of passengers transport system. The strategy for tackling these problems has been for years to consider adding more capacity to the transport supply system, through huge investments in transport infrastructure. Best utilization of available transport services and facilities is an urgent necessity. Methods developed in the theory of optimization, through making use of advanced computation technology, would allow one to make experimental analysis and evaluation of different policies and strategies for better understanding of the transportation problem and to select a solution for efficient utilization of resources.

This paper presents a methodology for transport modes operation analysis for different policies and strategies to be simulated in order to reach optimal goals. The performance and efficiency of transport modes operation are formulated in a framework as an output maximization process of an objective function, subject to state variables, decision variables, constraints and variable bounds. Four main traffic operation strategies which would have great impacts on urban transportation performance and efficiency were analyzed, each strategy contains heuristics of many trial values of decision variables. The overall methodology is seeking global optimality.

The research output revealed two important indicators for alternative transport systems evaluation; Mode Efficiency Factor and transport system passenger supply Efficiency Index. The efficient transport system supply that satisfies a certain demand is attained. Moreover, an identification and clarification of most compatible transport modes, suitable for passenger demand sharing, that would give optimal performance indicators are documented.

KEYWORDS: Urban passengers; Transportation Modes; Optimization; Operation Performance; Operation Efficiency

\section{INTRODUCTION}

Most cities all over the world are suffering from acute traffic problems causing congestion, slow of movement and environmental drawbacks, due to increasing carownership, growing economy, growing travel demand. Transport mobility and easy of 
access in urban areas are a necessity for promoting and growing economic expansion and development. The provision of transport supply is limited by funding insufficiency; also transportation facilities cannot increase in short period to match the growing demand. Therefore, best utilization of the existing facilities; i.e. enhancement of the existing transport system performance and efficiency is an urgent need [UITP, 1991]. The transportation efficiency can be defined as: the extent to which a certain transportation input can meet the travel demand of people in a transportation system [Yuan \& Lu, 2005].

Transportation problem is a combination of vehicles, route, economics, computation technology and mathematical optimization [Fusco, et. al, 2002]. Traffic management seeks to improve movement of people and goods, not necessarily vehicles, by contributing to the improvements of the traffic related environment. Traffic management aims to adjust, adopt, manage and improve the available transportation services and facilities to meet specified objectives without restoring to new infrastructure constructions. It involves development and use of physical and policy measures to achieve the most efficient use of traffic services and facilities to meet passengers demand at low cost solution to the problem [Cracknell, 2000; OECD ,1995].

Traffic congestion management measures are usually considered as (demand/supply) types [Paulley et. al, 2006]. "Demand side" measures are designed to reduce car demand on the system by increasing vehicle occupancy, reducing the need to travel during peak periods or reducing the need to travel specific locations by proper land use planning. "Supply side" measures are designed to adopt increasing public transport performance, policies and measures that enables efficient utilization of existing facilities and services (supply based strategies) [Paulley et. al, 2006].

Optimization models are used widely in most areas of decision-making, such as engineering design and financial portfolio selection [Arsham, H., 1994]. A mathematical optimization model consists of an objective function and a set of constraints in the form of a system of equations or disparities. Methods developed in the theory of optimization making use of advanced computation technology; would allow one to make experimental analysis and evaluation of different policies and strategies for better understanding of transportation problem and to select solutions for efficient utilization of available resources [Borndo et. al, 1998].

This paper presents a methodology for transport modes operation analysis for different policies and strategies to be simulated to reach optimal goals. Transport modes operation performance and efficiency variables are formulated in a framework as an output maximization process of objective function, subjected to state input variables, decision variables, constraints and variable bounds.

\section{URBAN TRAFFIC OPERATION PROBLEM DESCRIPTION AND CATEGORIZATION}

For small networks as the case of medium size cities, passengers demand is grouped into traffic zones. Each zone has been associated with; one zone centroid, group of passengers with their associated Origin / Destination (O/D) trip desires which are concentrated at zone centroid. Transport modes supply services of given vehicles carrying capacities are routed in an environment to pick-up and deliver passengers 
demand. Selection of best route (trunk route) is done by deterministic methodology guided by criterion. One would propose an algorithm that selects a route on the base of shortest path that connects pairs of terminals and serves the greatest number of (O/D) pairs. Route generated is jointed at main nodes (Zone-centroids) [Pages et. al, 2006].

The scope of research is a practical methodology to identify route and associated passengers' modes, flow rates to serve demand and that leads to minimize overall transport system costs. In this case transport problem is solved as static problem, since each zone pair is taken independently. The problem treated is stochastic in nature, both in terms of network conditions and in future occurrence of demand points. A possible way to tackle the entire problem would be to solve in different stages through discrete mathematics and optimization process. This approach leads to a better understanding of transportation system.

\section{PROBLEM FORMULATION}

The aimed approach is to develop a procedure for urban passengers transport modes operation through discrete mathematics and optimization to achieve the most efficient use of transport services and facilities to meet demand at minimum overall transport costs.

Dynamics of passengers transportation problem add a level of difficulty (compared to static problem), mainly when the demand is not known in advance. A possible way to tackle the problem would be to solve it as a static one in different stages through discrete mathematics and optimization process, each zone pair is taken independently.

Static case is used when the dimensions of the problem is small (like the case of medium size cities) [Pages et. al, 2006]. That scheme does not consider passengers behavioral models (modal split is assumed given).

In a current problem solution; passengers are assigned to use modes at proposed passengers' shares (Decision variables). The road passengers transport problem fits into category of optimization problem in which passengers have to be assigned to transport services and facilities fulfilling some constraints to achieve the most efficient use of transport system facilities and services.

The main elements of constrained optimization process are:

1. Basic Input Data Module: This would require data such as; vehicles type, vehicle characteristics and road link (segment) characteristics.

2. Decision Variables Module: Decision variables which influence the level of transport system performance and efficiency these would require data such as;

- Vehicle carrying capacities, vehicle flow rates, etc.

- Assigned passengers share (\%) to modes.

- Assigned mode priority.

The values of variables are not known when one would start the problem solution. Decision variables mean; if (value) is included in the solution, the (result) corresponding decision variable is (so).

3. Objective Function Module: It measures the desirability of a feasible solution that is a single number associated to every solution, (time, cost, passengers); solving the problem means to find such a best solution. It is a mathematical expression that 
combines the goals; (maximizing productive activity) (pass./hr/km) or (minimize overall transport costs).

4. Constraints Module: These are mathematical expressions that combine the variables to express limits on possible solutions; such as (desired level of service, link practical capacity constraint).

5. Variable Bounds: Variables usually have bounds not to be exceeded in the analysis process.

Problems are represented by mathematical models in which objective function is linear and constraints are given by linear equations, Linear Programming (LP) is used. If the relationships between variables are not linear functions, non linear programming methods are necessary. LP is most extensively used as a major technique for constrained optimization "planning using linear models". LP uses the simple method with bounds on variables. Model is based on the idea of "space" feasible solutions (all possible results of the planning process) [Watson, 2010]. Feasible solutions are not known, they are described implicitly by means of so-called constraints.

The mathematical expression of objective function and constraints are linear as follows:

\section{Objective Function:}

Maximize: $\quad C_{1} X_{1}+C_{2} X_{2}+\ldots \ldots \ldots C_{n} X_{n}$

Subject to: $\quad X_{1}>0 \quad, \quad X_{2}>0, \ldots \ldots \ldots . . . X_{n}>0$

, and Constraints:

$$
\begin{aligned}
& a_{11} X_{1}+a_{12} X_{2}+\ldots \ldots \ldots \ldots+a_{1 n} X_{n}<b_{1} \\
& a_{21} X_{1}+a_{22} X_{2}+\ldots \ldots \ldots \ldots+a_{2 n} X_{n}<b_{2} \\
& \cdot \\
& \cdot \\
& a_{m 1} X_{1}+a_{m 2} X_{2}+\ldots \ldots \ldots+a_{m n} X_{n}<b_{m}
\end{aligned}
$$

Where;

$$
\begin{aligned}
& a_{11} \quad a_{12} \ldots \ldots . a_{1 n} \quad b_{1} \\
& \begin{array}{llllll}
a_{21} & a_{22} & \ldots & a_{2 n} & b_{2}
\end{array} \\
& \cdot \cdot \cdot \cdot
\end{aligned}
$$

Set of known constraints parameters.

$$
\mathrm{X}_{1}, \mathrm{X}_{2} \ldots \ldots \mathrm{X}_{\mathrm{n}}
$$

Set of unknown variables which would be solved by simplex method. The constraints describe conditions that every feasible solution has to meet, and any value that satisfies all constraints is considered feasible solution [Watson, 2010].

\section{URBAN PASSENGER TRANSPORT PROBLEM IDENTIFICATION \& MODELLING}

\subsection{Problem Identification}

The road passenger transportation problem is an optimization problem in which drivers should be assigned to transport services, satisfying some constraints and minimizing 
some function cost [Lo'pez et. al, 2009]. The road passenger transport problem can be presented as follows:

1. Transport supply system (services \& facilities): links or segments of road which has the same characteristics, transport modes which share passenger transport, vehicle characteristics.

2. Passenger demand: passengers would move from origin (i) to destination (j) (pass./hr).

3. Sets of constraints:

a. All passenger demand is satisfied by supply system.

b. Mode assigned frequency would be $\leq$ the available fleet size of such mode.

c. Links (segments) capacity constraint i.e; (all traffic vehicles volume) should be $\leq$ segment practical capacity or a specific value to satisfy a desired level of service.

4. Operational planning is organized in a sequential process. Some co-ordination among the different transport modes is provided by a planning hierarchy; that simply:

a. $1^{\text {st }}$ mode schedules assigned passenger share $(\%)$ and or;

b. $\quad 2^{\text {nd }}$ mode schedules assigned passenger share $(\%)$ and or;

c. $3^{\text {rd }}$ mode schedules assigned passenger share $(\%)$

The intent is to find supply system flow rates to satisfy passengers demand over such segment a (trunk route) and to provide a maximum level of service at minimum costs.

The strategic and operative planning play an important role, that has inspired the development of large number of problems through decision variables (specific solutions), viewed as rule oriented planning [Lo'pez et. al 2009, Shahin 2006].

The main idea in this work is to organize the process as a sequence of steps at some (definable) level of detail. An advantage of this sequence is that the planner can always justify the reached results as a correct outcome of scheme (strategy). This approach is designed with an eye on desired objectives, a rule oriented decision process.

\subsection{Problem Modeling}

One would formulate the services approach in terms of variables, domains, and constraints with the following steps:

a. Services (variables) required to model the problem.

b. Domain of each mode variable (variable cells).

c. Sorting input data (parameters).

d. Sorting variables (decision variables) services have been ordered according to initial start or (lower cost mode is tried first).

e. Sorting constraints.

\subsubsection{The objective function}

The objective function is defined as following:

Maximize (productive activity) $=\mathrm{T}\left[\sum_{\mathrm{i}} \sum_{\mathrm{j}} \sum_{\mathrm{k}}\left(\mathrm{X}_{\mathrm{k}} * \mathrm{O}_{\mathrm{k}}\right)\right]$

Where: $\mathrm{T}=$ time duration, one hour is assumed.

$\mathrm{X}_{\mathrm{k}}=$ vehicle service rate frequency (veh./hr), 


$$
\begin{aligned}
& \mathrm{O}_{\mathrm{k}}=\text { average vehicle passenger occupancy of mode " } \mathrm{k} \text { " (pass./mode) } \\
& \mathrm{i}=\text { start point, and } \mathrm{j}=\text { end point }
\end{aligned}
$$

The objective function mathematical formula implies that the main variables in the productive activity of a segment are: Vehicle occupancy (pass./mode), vehicle frequency (veh./hr), desired traffic flow speed (kph), and Segment practical capacity (p.c.e's/hr).

Route segment is the basic unit of productive activity; is defined as the maximum (pass./hr) to be transported over a link (segment) of a route one directional flow at an acceptable level of service

\subsubsection{Link (Segment) Constraint}

$\sum_{\mathrm{i}} \sum_{\mathrm{j}} \sum_{\mathrm{k}} 1.15^{*}\left[\mathrm{X}_{\mathrm{k}} * \mathrm{E}_{\mathrm{k}}\right] \leq \mathrm{C} \quad$ where: $\quad \sum_{\mathrm{i}} \sum_{\mathrm{j}} \sum_{\mathrm{k}}[\mathrm{q}] \leq \mathrm{C}$

$\mathrm{X}_{\mathrm{k}}=$ vehicle service rate frequency (veh./hr)

$\mathrm{E}_{\mathrm{k}}=$ vehicle equivalency factor of mode (k) [p.c.e's]

$\mathrm{C}=$ link (segment) practical capacity (p.c.e's/hr)

$\mathrm{q}=$ traffic volume (all vehicles) (p.c.e's/hr)

Other vehicles (non pass. vehicles) link utilization is considered (15\%) of link capacity.

\subsubsection{Traffic Flow Speed Constraint [Wahdan and Sabry, 1995 ;} HCM, 2000]:

$$
\begin{aligned}
& \mathrm{U}_{\mathrm{s}}=\mathrm{U}_{\mathrm{f}}\left[1-\alpha\left(\mathrm{e}^{\beta \ln (\mathrm{q} / \mathrm{c})}\right)\right] \quad \text { or } \quad \mathrm{U}_{\mathrm{s}}=\mathrm{U}_{\mathrm{f}}\left[1-\alpha \quad(\mathrm{q} / \mathrm{c})^{\beta}\right. \\
& \text { where: } \mathrm{U}_{\mathrm{s}}=\text { desired traffic flow speed }(\mathrm{kph}) \\
&\left.\mathrm{U}_{\mathrm{f}}=\text { speed limits (one would consider } 60 \mathrm{kph}\right) \\
&(\mathrm{q} / \mathrm{c})=\text { traffic volume/ practical capacity } \\
&\alpha, \beta=\text { calibration factors (best assigned values are: } \alpha=0.7, \beta=2.2)
\end{aligned}
$$

\subsubsection{Related Mathematical Analysis Formulation:}

i. Supply System Carrying Capacity: (see analysis strategies input data)

Maximize Passenger No. (pass./hr) $=\mathrm{O}_{1} \mathrm{X}_{1}+\mathrm{O}_{2} \mathrm{X}_{2+} \mathrm{O}_{3} \mathrm{X}_{3}$ (Objective Function)(7)

Subject to; $\quad \mathbf{X}_{\mathbf{1}} \geq 0, \quad \mathbf{X}_{\mathbf{2}} \geq 0, \quad \mathbf{X}_{\mathbf{3}} \geq 0$

Where $\mathrm{X}_{1}=$ "Priv.+Taxi" $\quad \mathrm{X}_{2}=$ Micro-bus $\quad \mathrm{X}_{3}=$ Bus $\quad$ (vehicle frequency/hr)

$\mathrm{O}_{1}, \mathrm{O}_{2}, \mathrm{O}_{3}$ vehicle passenger occupancy of mode (passenger/mode) (input data)

ii. Lane Capacity Constraint [HCM 2000]:

$\mathrm{q}=1.15^{*}\left(\mathrm{E}_{1} \mathrm{X}_{1}+\mathrm{E}_{2} \mathrm{X}_{2+} \mathrm{E}_{3} \mathrm{X}_{3}\right) \leq 800$ p.c.e's/hr

Where, $E_{1}, E_{2}, E_{3}$ are vehicle equivalency factors

iii. Lane Speed Flow Constraint:

Us $=60 *\left(1-0.7 \mathrm{e}^{2.2 \mathrm{Ln}(\mathrm{q} / 800)}\right) \geq 30 \mathrm{kph} \quad($ Level of Service $(\mathrm{C}))$

iv. Fuel Consumption [Abbas, 1998]:

F.C. $=100 * \frac{C_{1} X_{1}+C_{2} X_{2}+C_{3} X_{3}}{O_{1} X_{1}+O_{2} X_{2}+O_{3} X_{3}} \quad$ (in lit/pass./100km)

Where, $\mathrm{O}_{1}, \mathrm{O}_{2}, \mathrm{O}_{3}, \mathrm{X}_{1}, \mathrm{X}_{2}$, and $\mathrm{X}_{3}$ are as defined before.

$\mathrm{C}_{1}, \mathrm{C}_{2}, \mathrm{C}_{3}$ are fuel consumption of mode (lit./km) (See analysis strategies input data) 
Supply transport system performance focuses on the degree to which segment can produce maximum activity at constraints and some environmental restrictions (e.g.; noise level ... etc.).

\section{METHOD USED AND ALGORITHM}

The algorithm used is divided into the following modules:

- Input data. - Decision variables.

- Heuristics (sequential process).

- Optimal target cell (maximizing \& minimizing).

- Objective function.

Figure 1 shows the modeling flow diagram. It is important to notice that the heuristics sequential process is solved once and its solution is used as initial solution for iterative process, the overall methodology seeking global optimality [Fusco et. al, 2002].

The Solver program tool was utilized for this study. The Solver program tool uses the Generalized Reduced Gradient (GRG2) optimization. It is used to determine maximum or minimum value of one cell (target cell) that contained within objective function by changing the other cells (the parameters of objective function) under defined constraints [Watson, 2010]. Solver is a part of suite commands called (what-if) analysis; a process of changing the value in cells to see how those changing affect the outcome formulas on (the working sheet). It is an iterative numerical method that involves plugging in trial values for the adjustable cells and noticing the results calculated by constraints cells and the optimal cell. Each trial is called iteration. Extensive analysis of the observed outputs and their rates of change as inputs are varied to guide the selection of new trial values. Solver works with a group of cells that are related directly or indirectly to the formula in target cell. It adjusts the values in the variable cells applying constraints or limitations placed in the solving problem.

\section{EXPERIMENTAL ANALYSIS OF OPTIMIZATION TECHNIQUE ON URBAN PASSENGERS TRANSPORT MODES OPERATION}

The developed model contains the principal structural relationships that exist among the various components involved in overall management of transport system. The user enters the basic input data, values of key parameters and selects the policies and strategies to be simulated. The model utilizes all these inputs through its mathematical formulations, algorithms, traces the requirements. It considers the effects that these components have on each other as well as on the overall performance of the transport system.

The following section demonstrates the model applicability in simulating four defined strategies.

\subsection{Analysis Strategies:}

Passengers transport structure of urban traffic is the composition of the proportion that all traffic modes share in total trips in urban traffic system. That is the proportion of all 
kinds of modes which passengers assign to travel. In urban traffic system all kinds of traffic modes share the passengers demand. There are great differences for different modes indicators, such as; carrying capacity, operation flow rate, operating speed, transportation cost.... etc. [Zang et. al, 2005].

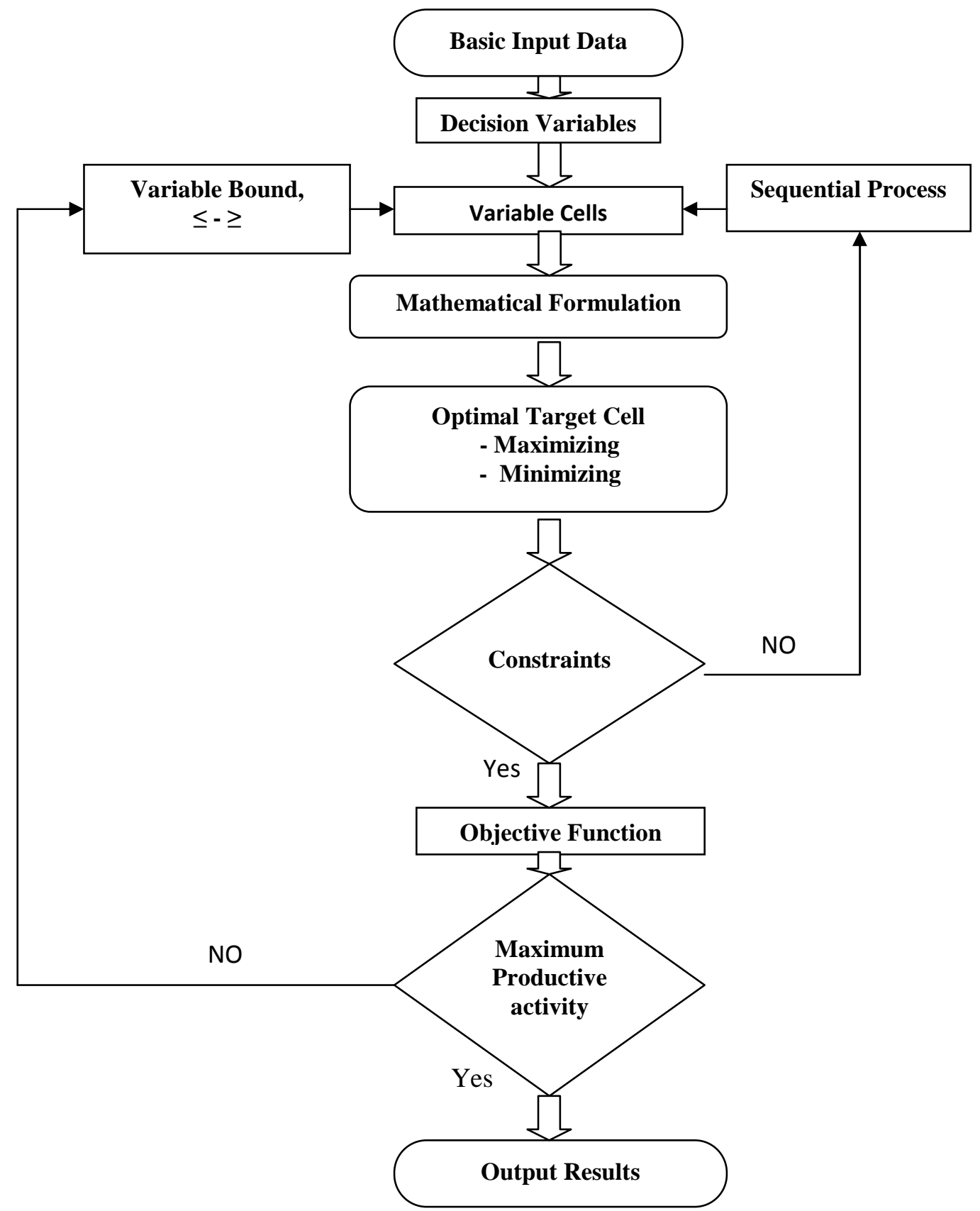

Figure 1: Urban Passengers Transport Problem simulation (Modeling Flow Diagram) 
Four main traffic operation strategies were analyzed. These strategies, denoted (A, B, C and D) would encompass different modes indicators and have great impacts on urban transportation system performance and efficiency. Each strategy contains heuristics of many trials values of decision variables. The over all methodology is seeking optimal goals. The main elements of each strategy associated by constrained optimization process (strategy objective, variable cells, decision variables, constraints, and input data) are given below.

\subsubsection{Strategy Objective:}

i. Maximizing Transport Supply System Carrying Capacity (pass./hr).

ii. Minimizing overall Transport system costs

\subsubsection{Decision Variables and constraints:}

The decision variables for each strategy are presented in the following table:

Table 1: Decision variables for considered strategies

\begin{tabular}{|c|c|}
\hline Strategy & Decision variables \\
\hline $\mathrm{A}, \mathrm{B}, \mathrm{C}$, and D & $\begin{array}{l}\text { - Supply Bus Transport fleet frequency varies between } 10 \text { and } 120 \\
\text { bus/hr. } \\
\text { - The number of assigned vehicles must be } \leq \text { available fleet. } \\
\text { - Micro-bus carrying capacity share percentage is variable (from } \\
\text { optimization process). } \\
\text { - Lane capacity constraint } \leq 800 \text { p.c.e's } / \mathrm{hr} \text {. } \\
\text { - Speed of Traffic flow }\left(\mathrm{U}_{\mathrm{s}}\right) \geq 30 \mathrm{kph} \text {. }\end{array}$ \\
\hline $\begin{array}{l}\text { ONLY } \\
\text { strategy A: }\end{array}$ & $\begin{array}{l}\text { - Assigned } 1^{\text {st }} \text { priority to "Priv.+Taxi" with carrying capacity } \\
\text { passenger share percentage varies }(5-70) \% \text { of total system } \\
\text { passengers' carrying capacity. }\end{array}$ \\
\hline $\begin{array}{l}\text { ONLY } \\
\text { strategy B: }\end{array}$ & $\begin{array}{l}\text { - Assigned Demand }\left(\mathrm{D}_{\mathrm{i}-\mathrm{j}}\right) \text { varies }(5000,4000,3000,2000 \text {, and } \\
1000) \text { pass./hr. } \\
\text { - Assigned } 1^{\text {st }} \text { priority to "Priv.+Taxi" with carrying capacity } \\
\text { passenger share percentage varies }(5-70) \% \text { of total system } \\
\text { passengers' carrying capacity. }\end{array}$ \\
\hline $\begin{array}{l}\text { ONLY } \\
\text { strategy C }\end{array}$ & $\begin{array}{l}\text { - Bus \& Micro-bus are only allowed in the right lane; "Priv.+Taxi" } \\
\text { are prohibited in the right lane (only public transport lane). }\end{array}$ \\
\hline $\begin{array}{l}\text { ONLY } \\
\text { strategy D: }\end{array}$ & $\begin{array}{l}\text { - Assigned } 1^{\text {st }} \text { priority to Bus Transport with fleet frequency varies } \\
\text { between } 10 \text { and } 120 \text { bus } / \mathrm{hr} \text {. }\end{array}$ \\
\hline
\end{tabular}

\subsubsection{Input Data (for all strategies):}

\section{i. Vehicle Characteristics:}

The following passenger transport modes are considered "Priv. \& Taxi", Micro-bus and Bus modes. Vehicle characteristics were reached from extensive literature reviews and are shown in the following table [Abbas, 1998; HCM, 2000]. It is worth noting that since Private and Taxi vehicles would nearly have the same vehicle characteristics, and for simplifying the analysis, they were assumed as a one vehicle type. 
Table 2: Vehicle characteristics [Abbas, 1998 ; HCM, 2000]

\begin{tabular}{|c|c|c|c|c|}
\hline Vehicle & Code & $\begin{array}{c}\text { Occupancy } \\
\text { (pass.) }\end{array}$ & P.C.E's & $\begin{array}{c}\text { Fuel Consumption } \\
\text { (lit./km) }\end{array}$ \\
\hline "Priv. Car \& Taxi" & $\mathrm{X}_{1}$ & 1.5 & 1 & 0.12 \\
\hline Micro-bus & $\mathrm{X}_{2}$ & 10 & 1.5 & 0.18 \\
\hline Bus & $\mathrm{X}_{3}$ & 40 & 2 & 0.35 \\
\hline
\end{tabular}

\section{ii. Link (Segment) Practical Capacity (p.c.e's/hr) and Flow Operation:}

The link (segment) is a part of shortest route (homogenous section) and considered as a one-way flow direction, with two lanes $(8 \mathrm{~m})$ width each. Lane practical capacity is assigned as 800 (p.c.e's/hr), associated with level of service (C) where traffic flow speed ( $\geq 30 \mathrm{kph}$ ). Traffic flow operation is considered as one of two cases: (a or b) as shown in figure2. In case (a) the public transports (Bus and Micro-bus) are assigned to the right lane. In case (b) all modes are assigned equally to each traffic lane (i.e. 50\% of all traffic modes).

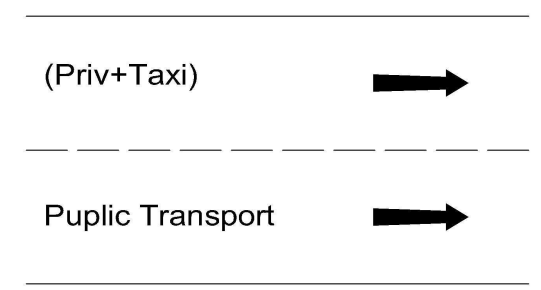

Case (a)

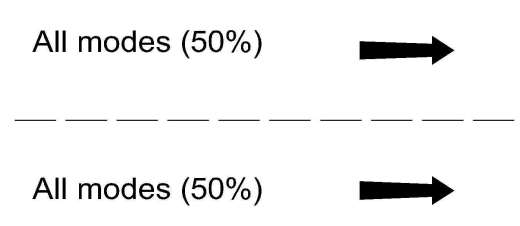

Case (b)

Figure 2: The Link Traffic flow cases

In case (a), analysis is directed to the right lane operation performance; since left lane would be assigned to "Priv.+Taxi" and other non passenger traffic with full lane utilization $\leq 600$ p.c.e's/hr i.e $\leq 900$ pass./hr. Link passenger carrying capacity in the right lane depends on each strategy results.

In case (b), $50 \%$ of all traffic modes is assigned to each lane. So analysis results of case (a) right lane would be applicable to case (b) associated with public transport vehicles frequency must be considered $50 \%$ and should coincide with case (a) analysis. Link carrying capacity is lane passengers' capacity multiplied by (2), other performance indicators are the same as in case (a). 


\section{RESULTS AND DISCUSSIONS}

For all strategies the following results were attained; transport modes maximum passenger carrying capacity, traffic flow speeds, fuel consumption, passenger delays, mode share (\%), mode frequency (veh./hr) and lane utilization (\%).

Factors which would have strong impacts on transport system operation performance and efficiency were investigated and analyzed. Also graphical relationships between these factors and system indicators are given bellow.

Figures $3 \mathrm{a}, \mathrm{b}, \mathrm{c}$, and d present mode passenger share (\%) effect on maximum passenger carrying capacity. In which, Figure 3 a represents "Priv.+Taxi" and Bus transport modes, Figure 3b represents "Priv.+Taxi" and Micro-bus, Figure 3c represents Micro-bus and Bus, and Figure 3d represents "Priv.+Taxi", Micro-bus and Bus.

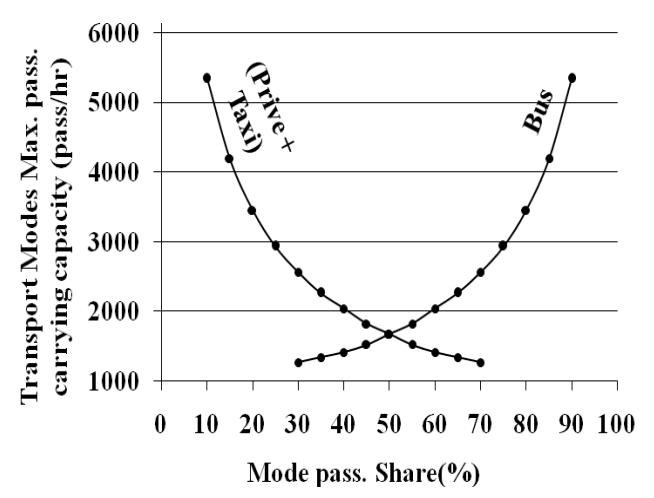

(a) Priv. \& Bus Modes

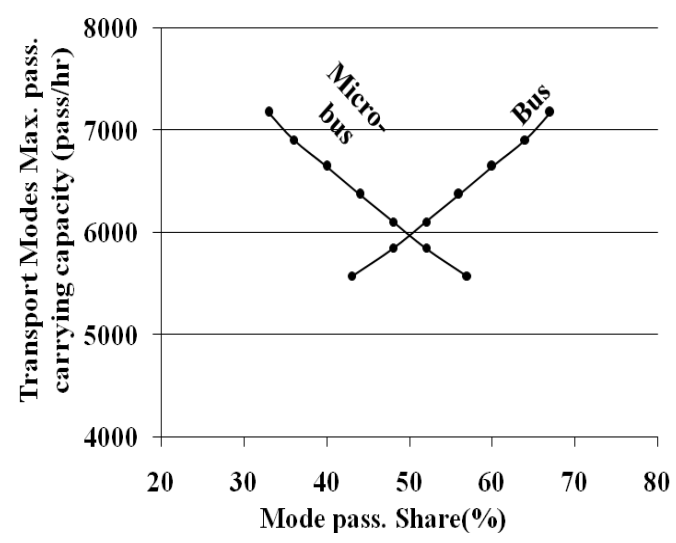

(c) Micro-bus \& Bus Modes

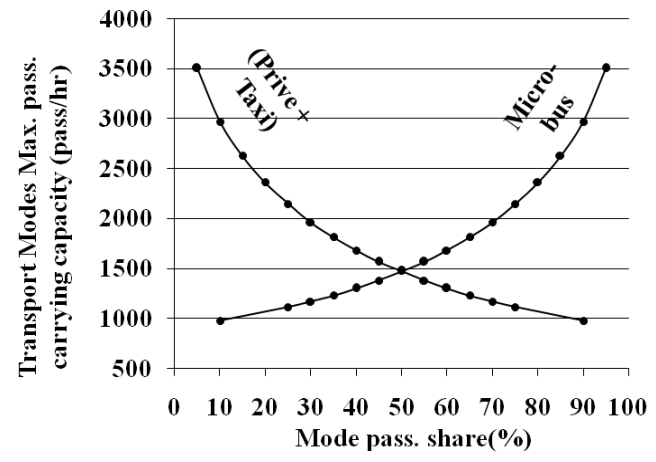

(b) Priv. \& Micro-bus Modes

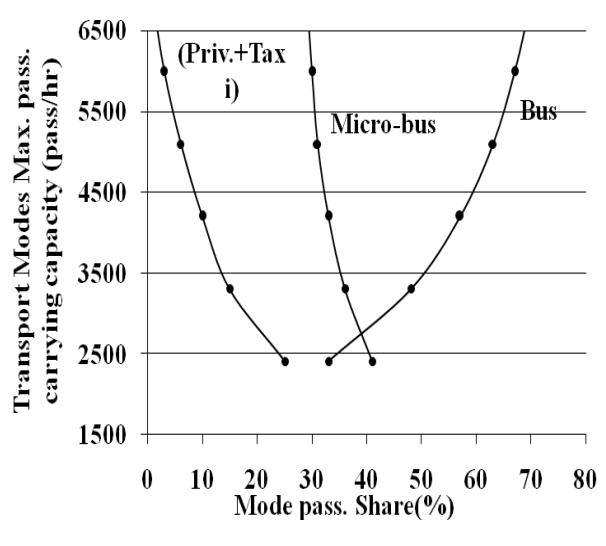

(d) Priv. , Micro-bus , \& Bus Modes

Figure 3: Mode pass. Share (\%) vs. Max. pass. carrying capacity (pass./hr); a) Priv. \&

Bus, b) Priv. \& Micro-bus, c) Micro-bus \& Bus, and d) Priv., Micro-bus, \& Bus Modes.

The Efficiency Index "E.I." of urban transportation systems is the relationship between the input of an urban transportation system and its capability of satisfying the 
transportation demand in the system. The greater the ratio, the higher the transportation efficiency is. Transport system Efficiency Index "E.I" = Transport system capacity / Optimal system capacity

Figure 4 shows the mode passenger share (\%) effect on transport system Efficiency Index "E.I". In which, the transport system Efficiency Index decreases rapidly as Private passenger share increases; for example as the Private passenger share increases from 10 to $15 \%$, this will cause a decrease in the E.I by about 19\% (i.e $1 \%$ increase in Private passenger share will lead to decrease in (E.I) by $4 \%$ ).

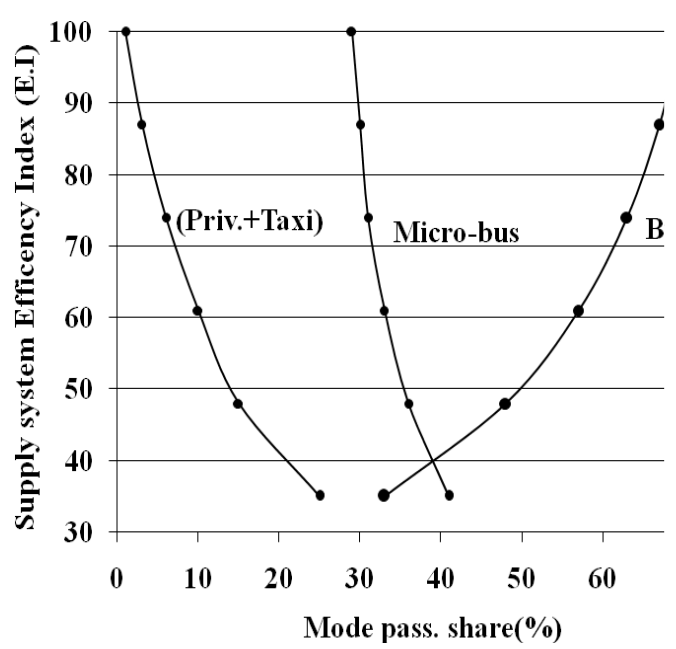

Figure 4: Mode pass. Share (\%) vs. Supply system Efficiency Index (E.I.) for Priv., Micro-bus, \& Bus Modes.

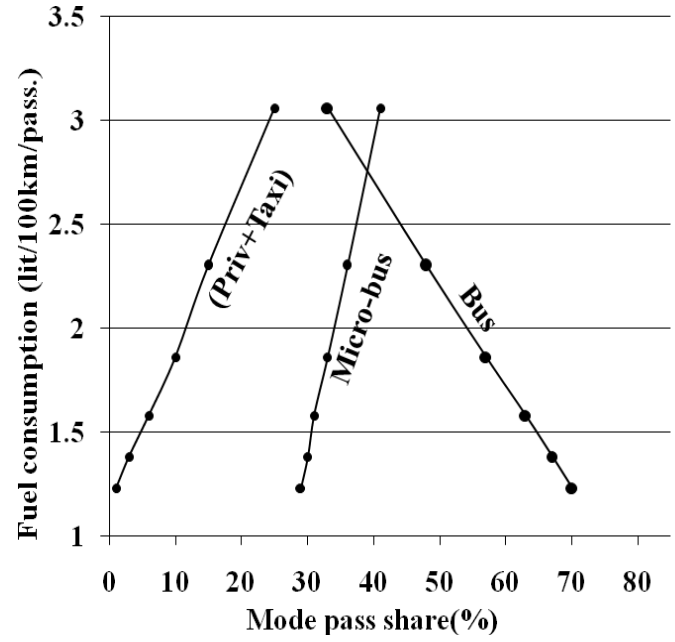

Figure5: Mode pass. Share (\%) vs. Fuel consumption (lit/100km/pass.) for Priv., Micro-bus, \& Bus Modes.

The following table shows the mode passenger share effect on passenger transport mode maximum carrying capacity pass./hr for strategies A, C, and D. The Optimal transport system passenger carrying capacity is equal to 7177 (pass/hr) and can be achieved form strategy C.

The Maximum transport system passenger carrying capacity as well as the minimum fuel consumption (lit/100km/pass.) can be attained from decision variables associated with modes passenger sharing $(\%)$ as shown in sequence process mix:

- "Priv.+Taxi" passenger sharing (\%) varies between (0-5)\%

- Micro-bus passenger sharing (\%) varies between (15-30)\%

- Bus passenger sharing (\%) varies between (70-80) \%

Table 4 presents the passenger demand level as was presented in strategy (B). The private passenger share increase (10-15) \% associated by demand level.

In strategy (B): For assigned passengers demand levels (5000 - 1000) pass./hr, as to maintain a level of service (C) where Us $\geq 30 \mathrm{kph}$, the appropriated "Priv.+Taxi" passenger share (\%) would be as shown in the following table: 


\section{Table 3: Mode passenger Share effect on maximum passenger Transport} system mode carrying capacity (pass./hr)

\begin{tabular}{|c|c|c|c|c|}
\hline \multicolumn{2}{|c|}{ Strategy } & $\mathbf{C}$ & D & $\mathbf{A}$ \\
\hline \multirow{3}{*}{$\begin{array}{c}\text { The Transport } \\
\text { Modes Passenger } \\
\text { Share }(\%)\end{array}$} & Priv.+Taxi " $\mathrm{X}_{1}$ " (\%) & 0 & 1 & 5 \\
\hline & Micro-bus " $\mathrm{X}_{1}$ " (\%) & 33 & 29 & 16 \\
\hline & Bus " $\mathrm{X}_{1}$ " (\%) & 67 & 70 & 79 \\
\hline \multicolumn{2}{|c|}{$\begin{array}{l}\text { Transport System (pass./hr) Carrying } \\
\text { Capacity }\end{array}$} & 7177 & 6885 & 6126 \\
\hline \multicolumn{2}{|c|}{ System Efficiency Index (E.I) (\%) * } & 100 & 96 & 85 \\
\hline
\end{tabular}

*Transport system Efficiency Index "E.I" = Transport system capacity / Optimal system capacity

Table 4: The passenger demand level as was presented in strategy (B).

\begin{tabular}{|l|c|c|c|c|c|}
\hline Demand (pass./hr) & 5000 & 4000 & 3000 & 2000 & 1000 \\
\hline Traffic Flow Speed (Us) (kph) & $34-15$ & $44-33$ & $52-46$ & $57-54$ & $59-58$ \\
\hline Us (\%) Decrease & 56 & 25 & 12 & 5 & 2 \\
\hline $\begin{array}{l}\text { Us (\%) Decrease for } \\
\text { “Priv.+Taxi” Pass. Share (1\%) }\end{array}$ & 11 & 5 & 2.4 & 1 & 0.4 \\
\hline
\end{tabular}

Table 5: Recommended "Priv.+Taxi”" Passenger Share (\%) for assigned demand levels (Strategy B)

\begin{tabular}{|l|c|c|c|c|c|}
\hline Assigned Demand (pass./hr) & 5000 & 4000 & 3000 & 2000 & 1000 \\
\hline $\begin{array}{l}\text { Recommended “Priv.+Taxi” } \\
\text { Pass. Share (\%) }\end{array}$ & $<10$ & $<15$ & $<20$ & $<35$ & $>35$ \\
\hline
\end{tabular}

Figure 5 shows the mode passenger share (\%) effect on transport system fuel consumption "F.C" (lit/100km/pass.). In which, the transport system fuel consumption "F.C." increases rapidly as the Private passenger share (\%) increases; for example as the Private passenger share increase by $(10-15) \%$, this would result in an in increase the F.C by about $25 \%$. In addition, as the Private passenger share increases by $1 \%$, the F.C would increase by $5 \%$.

Figure 6 shows the mode passenger share (\%) effect on traffic flow speed (Us) (kph). Results demonstrate the high effect of the Private passenger share $(\%)$ on the traffic flow speed, Us (kph); as the traffic flow speed decreases with the increase of the Private passenger share, associated with demand level. 


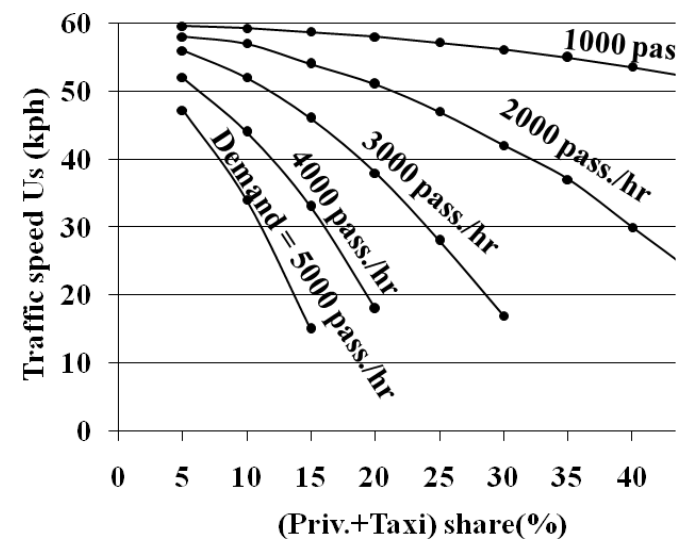

Figure 6: Priv. pass. Share (\%) vs. Traffic speed $(\mathrm{kph})$ for different demands

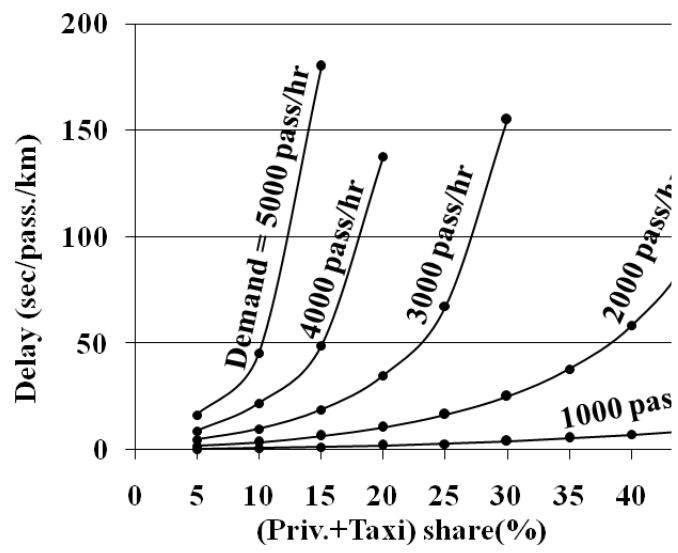

Figure 7: Priv. pass. Share (\%) vs. pass. Delay (sec/pass./km)

Figure 7 shows the mode passenger share (\%) effect on the traffic delays (sec/pass./km). Results show the high effect of the private passenger share $(\%)$ on the traffic delays; associated with passenger demand level (pass./hr).

\section{CONCLUSIONS}

Urban transport system operation performance and efficiency are the key indicators which determine the capacity and satisfaction of the transport system to meet desired travel demand. To improve the system operation performance and efficiency; the best way is to utilize effectively the existing services and facilities, through efficient operation policies.

The aimed approach of this research is to develop a procedure for urban passengers transport operation; through discrete mathematics and optimization techniques to achieve the most efficient use of transport services and facilities.

In this research experimental analysis using optimization techniques on urban passengers transport operation, through developed algorithm containing the principal structural relationships that exist among the various components involved in the overall management of the transport system.

Four main traffic operation strategies having great impacts on urban transportation system operation performance and efficiency were analyzed.

Analysis of the results is shown as relations between various parameters to transport system operation indicators and is presented through graphical relationships. The main element having impact on transport system operation performance and efficiency is "Priv.+Taxi" passenger share (\%).

Key findings of results related to defined strategies are:

1. The maximum transport system passenger carrying capacity (pass./hr) and the minimum fuel consumption (lit/100km/pass.) resulted from analysis would be associated with modes pass. share in sequence process mix as follows :

- "Priv.+Taxi" passenger sharing (\%) varies between (0\%-5\%)

- Micro-bus passenger sharing (\%) varies between (15\%-30\%)

- Bus passenger sharing (\%) varies between (70\%-80\%) 
2. Transport system efficiency decrease rapidly as "Priv.+Taxi" passenger share increases. For example as "Priv.+Taxi" passenger share increases from (10)\% to (15)\%, efficiency index would be decreased by (19)\%.

3. Transport system fuel consumption increase rapidly as (Priv.+Taxi) passenger share increase; e.g. as "Priv.+Taxi" passenger share increase from (10)\% to (15)\%, fuel consumption (lit/pass./100km) would be increased by $(25 \%)$.

4. Traffic flow speed (kph) decrease as "Priv.+Taxi" passenger share increase, associated with demand level e.g. as "Priv.+Taxi" passenger share increase from (10)\% to (15)\%, traffic flow speed would be decreased by: (56)\% associated with demand (5000 pass./hr), (25)\% associated with demand (4000 pass./hr), (12)\% associated with demand (3000 pass./hr) etc., with reference to traffic speed at passenger share at $(10) \%$.

5. For assigned passenger demand levels (5000 - 1000) (pass./hr); as to maintain a level of service $(\mathrm{C})$ where Us $\geq 30 \mathrm{kph}$, appropriate "Priv.+Taxi" pass. share would be as follows:

\begin{tabular}{|l|c|c|c|c|c|}
\hline Assigned Demand (pass./hr) & 5000 & 4000 & 3000 & 2000 & 1000 \\
\hline $\begin{array}{l}\text { Recommended “Priv.+Taxi”" } \\
\text { Passenger Share (\%) }\end{array}$ & $<10$ & $<15$ & $<20$ & $<35$ & $>35$ \\
\hline
\end{tabular}

6. For high demand levels; $>5000$ pass./hr passenger delays (sec/pass./km) would be very high for "Priv.+Taxi" passenger share $>10 \%$ since traffic speed would be decreased by $>50(\%)$ with reference speed $\geq 30 \mathrm{kph}$.

\section{ACKNOWLEDGMENT}

The authors would like to express their gratitude to Prof. Owais, M.A Prof. of transportation planning \& Traffic Eng., Civil Eng. Dept. Assuit Univ. for his valuable advice and recommendations which contributed to this research work.

\section{LIST OF REFERENCES}

1. Abbas, K., 1998. Estimation of consumption and requirement for bus system operation in Cairo. Civil Eng. Research Magazine, Al Azhar Univ. 20(3).

2. Arsham, H., 1994. Deterministic modeling: linear optimization with applications. http://home.ubalt.edu/ntsbarsh/opre640a/partviii.htm, accessed December 2010.

3. Borndo, R., Gro“tschel, M., Lo“bel, A., 1998. Optimization of transportation systems. Report no. 9809, Zurich, March 1998.

4. Cracknell, J. A., 2000. Experience in Urban Traffic Management and Demand Management in Developing Countries. Final Report, Department for International Development, UK.

5. Drowling R., 1997. Planning techniques to estimate speeds and service volumes for planning applications. National Co-Operative Highway Research Program (NCHRP) Report 387, Washington, D.C. 
6. Fusco, G., Gori, S., Petrelli, M., 2002. A heuristic transit network design Algorithm for medium size towns. Proceedings of 9th Euro Working Group on Transportation, Bari, Italy, pp. 652-656.

7. Highway Capacity Manual (HCM), 2000. TRB, National Research Council, Washington, DC.

8. Lo'pez, B., Muñoz, V., Murillo, J., Barber, F., Salido, M.A., Abril, M., Cervantes, M., Caro, L.F., Villaret, M., 2009. Experimental analysis of optimization techniques on the road passenger transportation problem. Journal of Engineering Applications of Artificial Intelligence 22, pp. 374-388.

9. OECD Scientific Expert Group, 1995. Congestion Control and Demand Management. Organization for Economic Cooperation \& Development (OECD), Paris, France, ISBN: 92-64-14315-7.

10. Paulley, N., Balcombe, R., Mackett, R., Titheridge, H., Preston, J.M., Wardman, M.R., Shires, J.D., White, P., 2006. The demand for public transport: The effects of fares, quality of service, income and car ownership. Transport Policy Journal 13(4), pp. 295-306.

11. Pages, L., Jayakrishnan, R., Cortés, C., 2006. Real time mass passenger transport network optimization problems. Transp. Res. Rec. pp 229-237.

12. Shahin, M., 2006. Optimization of traffic operation performance in urban areas. Alex. Eng. Journal 45(3), pp. 349 - 358.

13. (UITP), International Union of Public Transport International Commission on Traffic and Urban Planning (1991).

14. Wahdan, A., Sabry, M., 1995. Speed/Flow Relationships on Cairo Urban arterial roads. Civil Eng. Magazine, Al-Azhar University 17(1).

15. Watson, J, "Algorithms and Methods Used by Solver" Microsoft Office Excel Solver Program (2010).

16. Yuan, H., Lu, H., 2005. Evaluation and analysis of urban transportation efficiency in china. Proceedings of the Eastern Asia Society for Transportation Studies 3(3), pp. 323-333.

17. Zang, S., Zhou, W., Shao, C., 2005. Evaluation of urban passenger transport structure. Proceeding of Easter Aisha Society 5, pp. 441-449.

\section{" تحليل وتقييم أداء كفاءة تشغيل وسائل نقل الركاب في المناطق الحضرية "}

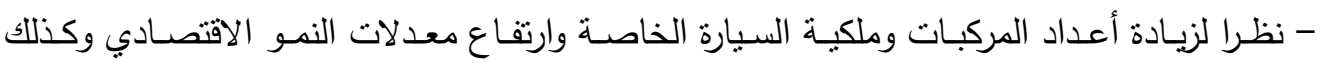

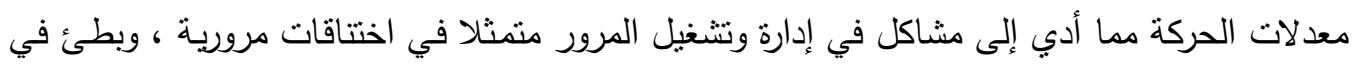
حركة سير المركبات وتدهور في أداء وكفاءة وسائل نقل الركاب الجماعية و الخاصنة.

- تركزت الحلول في الحقبة الاخيرة علي صرف إنفاقات هائلة في الإرتقاء بالبنية الأساسية للنقل

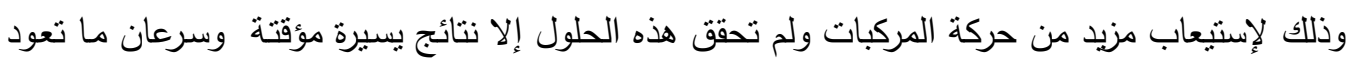
المشاكل المرورية إلي سابق ذكرها. 
- يهدف هذا البحث إلي إيجاد إطـار علمي يمكن من خلالمه التفهم الواضـح لكيفية تداخل العناصر والمدخلات المختلفة في إدارة وتشغيل المرور ونقل الركاب علي أداء وكفاءة قطاع النقل داخل المدن. - يركز هذا البحث علي إعداد هيكلية محاكاة في إطار تحليلي من خلال نموذج رياضي (Solver) قابل للتطبيق وذلك من خلال رياضة البحوث التطبيقية وتكنولوجيا الحاسبات المتقدمة - أمكن من خلاله إجراء العديد من الإختبارات لنظم سياسات و إستراتيجيات مختلفة وتحليل وتقييم نتائج فاعليتها علي أداء وكفاءة تشغيل وسائل نقل الركاب الجماعيـة والخاصـة وذللك بهدف تعظيم القدرات النقلية لهذه الوسائل (راكب . كم / ساعة) - النتائج التي تم التوصل إليها أوضحت تفهما واسعا للمدخلات والعناصر المختلفة التى تؤثز على أداء و كفاءة تشغيل و سائل النقل وكذلك علي إيجاد موشرات تعبر عن مستوي الأداء. - أيضا أمكن التوصل إلي كيفية تعظيم القدرات النقلية لهذه الوسائل مما يمكن من الإستفادة المثلي من الإمكانيات المتاحة وذللك في إطار مدخلات معينة لتحقيق اشتراطات خاصة. 